\title{
REKONSTRUKSI INTEGRALISTIK INSTRUMEN MATA UANG BERBASIS SYARIAH (DIGITAL GOLD CURRENCY)
}

\author{
Agus Faisal $^{1}$, Ahmad Nur Wahid ${ }^{2}$, Irma Yuliani ${ }^{3}$ \\ Universitas Islam Negeri Sunan Kalijaga Yogyakarta
}

$\triangle$ Corresponding Author:

Nama Penulis: Agus Faisal

E-mail: agus.faisal@uin-suka.ac.id

\begin{abstract}
Digital currency is the result of the evolution of the medium of exchange that continues to develop from time to time among the people. Changes in payment instruments from traditional systems to digital systems are expected to have a positive impact on payment traffic both in terms of speed, ease and security for the community. The DGC (Digital Gold Currency) study was explored in more depth using qualitative descriptive methods and the application of integralistic technology reconstruction. Narrative analysis starts from the study of the history of the development of currency types to the use of digital currencies, the advantages and benefits for the economy in general. Furthermore, the reconstruction of integralistic technology for the formation of DGC (Digital Gold Currency) was carried out by combining three concepts, including: first, the use of currency technology (digital money) can provide convenience and security for the community, second, the use of gold as a currency standard due to the stability of its value and its existence is universally recognized, Third, the application of Islamic values in the formation of currency (shari'ate money) by returning the function of money in accordance with Islamic sharia.
\end{abstract}

Key words: Digital Money; Gold Money; Shari'ate Money; Digital Gold Currency

\section{Abstrak}

Mata uang digital merupakan hasil dari evolusi alat tukar yang terus berkembang dari masa ke masa di kalangan masyarakat. Perubahan alat pembayaran dari sistem tradisional menuju sistem digital diharapkan mampu memberikan dampak positif terhadap lalulintas pembayaran baik dari sisi kecepatan, kemudahan maupun keamanan bagi masyarakat. Penelitian DGC (Digital Gold Currency) ini ditelaah lebih mendalam dengan menggunakan metode deskriptif kualitatif serta penerapan rekonstruksi teknologi integralistik. Analisis naratif dimulai dari studi history perkembangan jenis mata uang hingga pada penggunaan mata uang digital, keunggulan serta manfaatnya bagi perekonomian secara umum. Selanjutnya rekonstruksi teknologi integralistik pembentukan DGC dilakukan dengan memadukan tiga konsep, diantaranya, pemanfaatan teknologi mata uang (Digital Money) dapat memberikan dampak kemudahan dan keamaan bagi masyarakat, penggunaan emas sebagai standar mata uang disebabkan stabilitas nilainya dan diakui secara universal, Penerapan nilai syariah dalam pembentukan mata uang dengan mengembalikan fungsi uang sesuai syariah Islam.

Kata kunci: Digital Money; Gold Money; Shari'ate Money; Digital Gold Currency 


\section{PENDAHULUAN}

Sistem perekonomian dunia dalam perkembangannya telah mengalami banyak pergeseran dan rekonsiliasi sistem. Pada mulanya sistem kapitalis yang menjadi kiblat sistem perekonomian dunia dianggap banyak menimbulkan praktik kekuasaan pasar dan intervensi pemeritah, kemudian sistem ekonomi sosialis dengan wajah barunya berupaya melunakkan kekuasaan pasar (Rachbini, 2002). Namun demikian menurut Capra, ketidakseimbangan secara makro serta problem yang muncul seperti tindak kejahatan maupun kekacauan sosial dalam kenyataanya semakin meningkat (Chapra, 1999).

Permasalahan sistem ekonomi tersebut terjadi merupakan konsekuensi alamiah dan dapat diperkirakan secara baik atas suatu cacat struktural dalam sistem-sistem itu sendiri. Cacat tersebut timbul dari konflik dalam tujuantujuan yang berakar pada moral dan agama. Untuk itu, perlu diciptakan sebuah sistem yang berkarakter religious, bermoral, dan humanis. Sistem ekonomi Islam yang dipandang sebagai sistem ekonomi alternatif. Dalam sistem ekonomi Islam ada beberapa nilai instrumental yang strategis yang mempengaruhi tingkah laku ekonomi seorang, masyarakat, dan pembangunan ekonomi pada umumnya. Pertama yaitu perintah menunaikan zakat, kedua yaitu pelarangan atas praktik riba, ketiga kerjasama ekonomi, dan keempat adalah jaminan sosial.

Sebagai salah satu komponen penting penggerak perekonomian, uang menempati posisi sebagai bagian fungsi yang terintgrasi dalam suatu perekonomian. Penggunaan dolar sebagai standar mata uang dunia saat ini ternyata rawan terhadap gejolak ekonomi. Munculnya krisis di berbagai belahan dunia adalah akibat ketidakstabilan dalam sistem keuangan dan moneter. Dalam sejarah komoditi uang sebagai standar, terdapat dua standar umum yang digunakan yaitu standar emas (gold currency standards) dan standar perak (silver currency standards).

Dalam sejerah peradaban Islam bangsa Arab pernah menggunakan dinar dan dirham sebagai alat transaksi. para pedagang Arab ini berinteraksi dengan banyak bangsa. Saat pulang dari Syam, mereka membawa dinar emas Romawi (Byzantium), dan yang pulang dari Iraq, mereka membawa dirham perak Persia (Sassanid). Cerita uang dalam dunia Islam terus berlanjut sepanjang sejarah hingga beberapa saat menjelang Perang Dunia I ketika dunia menghentikan penggunaan emas dan perak sebagai mata uang. Perubahan evolusi mata uang dapat dilihat pada Gambar 1. 


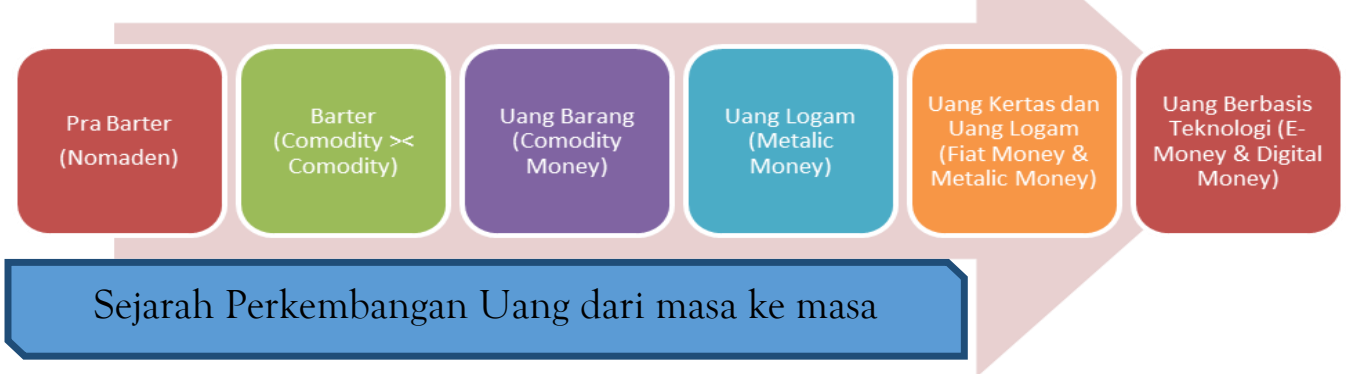

Gambar 1. Sejarah Perkembangan Uang Sumber: diolah peneliti (2018)

Penggunaan uang kertas pada awalnya merupakan bukti-bukti pemilikan emas dan perak sebagai alat/perantara untuk melakukan transaksi. Dengan kata lain, uang kertas yang beredar pada saat itu merupakan uang yang dijamin 100\% dengan emas atau perak. Pada perkembangan selanjutnya, masyarakat tidak lagi menggunakan emas (secara langsung) sebagai alat pertukaran. Sebagai gantinya, mereka menjadikan 'kertas-bukti' tersebut sebagai alat tukar yang kemudian dikenal dengan istilah Fiduciari atau Fiat Money (Christopher dan Bryan, 1994).

Beberapa problematika dalam pengunaan uang kertas dapat dilihat dari berbagai sudut pandang. Uang kertas sampai sekarang penuh dengan kegagalan yang tragis selama tiga abad terakhir (Iqbal, 2007). "Seigniorage" Pada Uang Kertas. Menurut Syekh Taqiyuddin an-Nabhany, secara politis langkah yang dilakukan oleh AS untuk menghentikan pengkaitan Dollar dengan emas adalah didorong oleh keinginan AS untuk memposisikan dollar sebagai standar moneter internasional hingga menguasai pasar moneter internasional. Oleh karena itu standar emas kemudian dianggap tidak lagi dapat dipergunakan di dunia.Standar moneter Bretton Woods kemudian hancur dan kurs pertukaran mata uang terus berfluktuasi tidak terkendali sampai detik ini (an-Nabhany, 1999).

Berbeda dengan Saidi (2007) yang memiliki pandangan bahwa uang kertas hukumnya haram karena termasuk riba sehingga tidak sah ketika digunakan sebagai alat tukar maupun untuk membayar zakat. pemikiran mengenai muamalat dari Zaim Saidi adalah mengenai uang kertas. Keberadaan uang kertas bisa memicu praktek riba seperti anggapan Zaim Saidi dalam bukunya Ilusi Demokrasi; Kritik dan Otokritik Islam (2007). La Tuzhlimuna Wa La Tuzhlamun. Tidak ada yang menzalimi atau tidak ada yang terzalimi sebagai mana kaidah hukum Islam (Saidi, 2007).

Di era modern perkembangan teknologi semakin pesat. Perkembangan teknologi juga membuat sistem pembayaran mengalami perkembangan dari transaksi tunai menuju transaksi non tunai. Perubahan dari penggunaan 
uang logam dan kertas menuju kepada mata uang berbasis elektronik (electronic money) memberikan kemudahan kepada para penggunaanya. Sistem ini berupaya mengakomodir setiap kebutuhan masyarakat dalam hal pemindahan dana secara cepat, aman, dan efisien. uang elektronik (E-Money) akan semakin berinovasi dan terus berkembang meningkatkan fasilitas kemudahan dalam setiap transaksi.

Pada era penggunaan teknologi yang semakin canggih, rekonstruksi sistem keuangan adalah suatu keniscayaan. Tidak hanya uang elektronik, penggunaan mata uang digital ikut mengambil posisi penting dalam sejarah perkembangan jenis mata uang. Mata uang digital telah memasuki pasar transaksi masyarakat. Namun masalahnya, bagaimana penggunaan mata uang digital tersebut tetap sesuai dengan prinsip syariah islam. Sehingga perlu adanya rekonstruksi teknologi integralistik yang memadukan konsep digitalisasi sistem dengan Sharia Money. Tujuan dari penelitian ini adalah memaparkan suatu bentuk produk rekonstruksi sistem keuangan yang dikenal dengan Digital Gold Currency yang lahir dari dua konsep yang terintegrasi.

\section{KAJIAN PUSTAKA}

Penelitian mengenai perkembangan instrumen mata uang telah dilakukan oleh beberapa peneliti terdahulu. Diantaranya yaitu Penelitian oleh Yaacob (2012) dalam "Study of Implementasi Gold Dinar as Currency." Dalam penelitiaannya, Salmy memperoleh hasil bahwa mata uang dinar belum mampu sepenuhnya diimplementasikan. Hal tersebut disebabkan karena kurangnya pengadaan insfratruktur fisik pada emas itu sendiri, alasan lain disebabkan oleh kurangnya kesadaran masyarakat untuk memperbaiki sistem moneter suatu negara dengan cara kembali kepada mata uang emas.

Penelitian yang sama dilakukan oleh Yacoob (2012) dengan judul "Gold Dinar As A Supreme Currency: Review Based On The History Of Islamic Civilisation". Melalui pendekatan sejarah, hasil penelitian tersebut menunjukkan bahwa dinar merupakan mata uang pertama umat muslim. Dinar juga berperan sebagai symbol kekuatan umat muslim dari zaman kekhalifahan hingga runtuhnya kekaisaran ottoman pada tahun 1924. Hal tersebut disebabkan karena dinar memiliki kestabilan nilai dalam sejarah mata uang.

Berikutnya oleh Tazkiyaturrohmah (2016) meneliti tentang Transaksi Uang Elektronik di tinjau dari Hukum Bisnis Syariah. peneliti menyimpulkan bahwa penggunaan uang elektronik dalam transaksi moneter mampu menekan tingkat kejahatan pencurian dan perampokan, dengan begitu salah satu asas maqasid syariah Hifz al-Maal berlaku. 
Penelitian Bahri (2010) membahas "Konsep Uang Elektronik dan Peluang Implementasinya pada Perbankan Syariah." Penelitian tersebut memberikan respon positif terhadap pengimplementasian unag elektronik sebagai alat transaksi pada perbankan syariah, serujuk dengan peraturan Bank Indonesia No.11/12/PBI/2009. Selain itu Mulyanto (2015) dalam penelitiannya menemukan penggunaan teknologi cryptocurrency dengan menggunakan bitcoin memungkinkan untuk dibangunnya sebuah sistem terintegrasi saling bertukar data dalam suatu jaringan peer-to-peer.

Pada dasarnya penelitian ini memiliki persamaan dan perbedaan terhadap penelitian terdahulu. Sama membahas tentang isu perkembagan instrumen mata uang. Sedangkan perbedaannya terletak pada pengembangan desain sistem pada instrumen mata uang itu sendiri. Dalam penelitian ini, penelitia ingin memadukan desain sistem instrumen mata uang yang berkarakter digital dengan merekonsiliasi nilai mata uang tersebut kepada standar emas dan disesuaikan dengan nilai-nilai keislaman.

\section{Teori uang}

Uang merupakan alat tukar yang dapat diterima secara umum, alat tukar itu sendiri dapat berupa apapun selama dapat diterima secara umum atau masyarakat dalam proses penukaran barang dan jasa (Mulyanto, 2015). Uang dalam literatur fiqh disebut dengan tsaman atau nuqud (jamak dari naqd). Abdullah bin Sulaiman al-Mani' di dalam Buhuts fi al-Iqtishad alIslami (1996) dan Muhammad Rawas Qal'ah Ji di dalam (al-Mu'amalat alMaliyah al-Mu'ashirah fi Dhau' al-Fiqh wa al-Syari'a,1999) mendefinisikan:

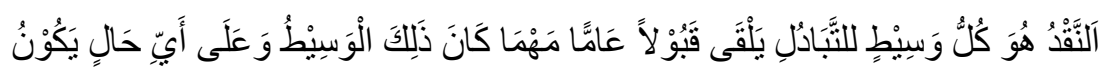

Artinya: "Naqd (uang) adalah segala sesuatu yang menjadi media pertukaran dan diterima secara umum, apa pun bentuk dan dalam kondisi seperti apa pun media tersebut."

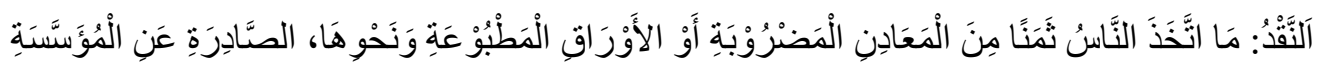

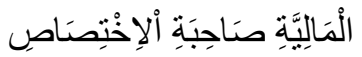

Artinya: "Naqd adalah sesuatu yang dijadikan harga (tsaman) oleh masyarakat, baik terdiri dari logam atau kertas yang dicetak maupun dari bahan lainnya, dan diterbitkan oleh lembaga keuangan pemegang otoritas."

Uang setidaknya memiliki 3 fungsi yaitu: sebagai alat tukar, penyimpan nilai dan satuan hitung. Pada perjalannya uang mengalami perkembangan dan berevolusi sehingga dikenal uang dengan berbagai macam jenis, yaitu: 
1. Dinar dan Dirham

Sejarah mencatat bahwasannya dinar dirham pernah menjadi satu-satunya mata uang di zaman Rasulullah (Billah, 2010). Dinar dan dirham memiliki nilai sepertihalnya emas dan perak. Sehinga nilainya tidak bisa lepas dengan harga emas dan perak dunia. Walaupun terkadang terjadi kenaikan dan penurunan nilai mata uang, akan tetapi naik dan turunnya relatif kecil dan tetap memiliki nilai intrinsik yang jelas dan pasti.

Sebagai salah satu entitas yang layak digunakan sebagai alat transaksi, Sukirno (2010) menyampaikan bahwa emas dan perak dapat digunakan sebagai mata uang, harus memiliki ciri-ciri khusus, antara lain banyak yang menyukai karena dapat digunakan sebagai perhiasan, emas dan perak memiliki kualitas yang sama, tidak mudah pudar atau rusak, dan dapat dibagi dengan mudah, membutuhkan pengorbanan dan biaya untuk mendapatkan karena barangnya yang terbatas, nilainya stabil, karena kualitasnya bertahan jangka panjang, memperlancar stabilitas sistem moneter.

2. Uang Elektornik

Bank for International settlement (BIS) mendefinisikan uang elektronik sebagai produk yang memiliki nilai tersimpan (stored value) dalam media elektronik/digital. Berdasarkan peraturan Bank Indonesia No.11/12/PBI/2009, yang berlaku sejak 13 April 2009 Uang Elektronik (electronic money) adalah alat pembayaran yang memenuhi unsur berikut:

a) Diterbitkan atas dasar nilai uang yang disetor terlebih dahulu oleh pemegang kartu kredit.

b) Nilai uang disimpan secara elektronik dalam suatu media seperti server atau chip.

c) Digunakan sebagai alat pembayaran kepada pedagang yang bukan merupakan penerbit uang elektronik tersebut.

d) Nilai uang elektronik yang disetor oleh pemegang dan dikelola oleh penerbit bukan merupakan simpanan sebagaimana dimaksud dalam Undang-Undang yang mengatur mengenai perbankan.

Elektronik money memiliki beberapa kelebihan dibandingkan dengan alat pembayaran lainnya, yaitu dengan mengedepankan kecepatan, kemudahan, serta efisiensi dalam melakukan transaksi (Prastiti, 2015). 


\section{Ekonomi moneter perspektif konvensional dan ekonomi Islam}

Ekonomi Islam menjelaskan segala fenomena tentang perilaku pilihan dan pengambilan keputusan dalam setiap unit ekonomi dengan memasukkan tata aturan syariah sebagai variabel independen. Uang dalam ekonomi makro merupakan unsur yang perlu diperhitungkan. Uang merupakan bagian yang tidak dapat dipisahkan dari kehidupan, bahkan keberadaan uang dapat menghindari kegiatan riba fadl.

Ada perbedaan konseptual mengenai uang dalam literasi sistem kapitalis dan sistem ekonomi Islam. Dalam sistem perekonomian kapitalis, uang tidak hanya sebagai alat tukar yang sah (legal tender), melainkan juga dapat sebagai komoditas. Ketika uang diperlakukan sebagai komoditi, Pasar uang semakin berkembang dan sebagian besar transaksi uang tidak berlandaskan motif transaksi yang riil, bahkan sebagian besar diantaranya mengandung motif spekulasi (Huda, 2009). Konsep uang dalam ekonomi Islam merupakan alat transaksi dan alat tukar, bukan sebagai komoditi. Fungsi uang dalam konsep Islam adalah memperlancar transaksi sektor riil sehingga tidak diperlukan adanya double coincidence needs. Fungsi ini secara konsisten dipertahankan dalam konsep Islam, sehingga transaksi di pasar uang selalu terkait dengan transaksi di pasar barang (Karim, 2008).

\section{METODE PENELITIAN}

Penelitian ini menggunakan metode deskriptif kualitatif serta rekonstruksi teknologi integralistik. Analisis naratif bertujuan untuk mengumpulkan berbagai informasi mengenai perkembangan uang digital, kelebihan serta kekurangan yang ditemukan dalam melakukan trasaksi uang digital. Selanjutnya pada tahap rekonstruksi teknologi integralistik berupaya untuk memadukan 3 konsep utama dalam pembentukan uang digital yang terintgrasi, yaitu pemanfaatan teknologi mata uang (digital money), penggunaan emas sebagai standar mata uang (gold currency) dan penerapan nilai-nilai syariah dalam pembentukan mata uang (sharia rules) dengan mengembalikan fungsi uang sesuai dengan prinsip-prinsip syariah Islam.

\section{HASIL DAN PEMBAHASAN}

\section{Analisis Mata Uang berbasis Teknologi}

Perkembangan teknologi yang semakin meningkat turut serta mendorong masyarakat untuk memperoleh kecepatan, kemudahan dan keamanan dalam melakukan transaksi keuangan (Mulyanto 2015). Salah satu wujud dari pengaruh perkembangan teknologi dalam bidang keuangan yaitu munculnya sistem pembayaran secara elektronik. Dalam penelitian yang dilakukan oleh Bank Indonesia menyatakan bahwa sistem pembayaran yang 
baik akan membawa dampak yang sangat signifikan bagi stabilitas sistem keuangan (Untoro, 2014). Bank Indonesia juga sudah mengeluarkan PBI No.11/12/PBI/2009 tentang uang elektronik (electronic money). Data Bank Indonesia per 14 September 2017 terdapat 26 perusahaan yang tercatat sebagai daftar penyelenggara uang elektronik. Tabel 1. merupakan data statistik sistem pembayaran oleh BI.

Penggunaan e-money sebagai media pembayaran semakin meningkat dari waktu ke waktu. Hal tersebut menjadi bukti bahwa perkembagan teknologi yang telah merambah hingga sistem moneter telah memberikan dampak kemudahan kepada masyarakat. Seluruh perkembangan sistem pembayaran baik perkembangan dari sisi alat pembayaran, transaksi maupun penyelenggaraan sistem pembayaran itu sendiri memberikan konsekuensi terhadap tingkat risiko yang harus dikelola oleh para pengguna. Bitcoin adalah satu-satunya criptocurrency yang telah banyak digunakan oleh masyarakat luas. Bitcoin merupakan mata uang digital yang memanfaatkan jaringan peer-to-peer network sebagai media distribusinya dengan menggunakan protokol kriptografi canggih (Mulyanto, 2015). Bitcoin pertama kali dikenalkan oleh Nakamoto sashinto pada tahun 2009.

Tabel. 1 Statistik Sistem Pembayaran Transaksi Uang Elektronik

\begin{tabular}{|c|c|c|c|}
\hline Periode & & Volume & Nominal \\
\hline Tahun 2010 & & 26.541 .982 & 693.467 \\
\hline Tahun 2011 & & 41.060 .149 & 981.297 \\
\hline Tahun 2012 & & 100.623 .916 & 1.971 .550 \\
\hline Tahun 2013 & & 137.900 .779 & 2.907 .432 \\
\hline Tahun 2014 & & 203.369 .990 & 3.319 .556 \\
\hline Tahun 2015 & & 535.579 .528 & 5.283 .018 \\
\hline Tahun 2016 & & 683.133 .352 & 7.063 .689 \\
\hline \multirow[t]{4}{*}{ Tahun 2016} & September & 58.023 .844 & 544.916 \\
\hline & Oktober & 61.294 .423 & 584.319 \\
\hline & November & 66.316 .596 & 831.972 \\
\hline & Desember & 79.228 .422 & 749.766 \\
\hline \multirow[t]{8}{*}{ Tahun 2017} & Januari & 58.435 .893 & 665.791 \\
\hline & Februari & 58.573 .280 & 812.282 \\
\hline & Maret & 62.985 .770 & 746.397 \\
\hline & April & 55.631 .892 & 633.561 \\
\hline & Mei & 60.620 .306 & 879.108 \\
\hline & Juni & 51.969 .836 & 1.019 .650 \\
\hline & Juli & 68.685 .872 & 1.141 .504 \\
\hline & Agustus & 62.565 .183 & 790.699 \\
\hline
\end{tabular}


Keberadaan uang digital atau yang disebut digital currency belum banyak dibahas dalam Islam karena sifatnya yang sangat kontemporer. Di Indonesia, DSN-MUI juga belum menerbitkan fatwa tentang keberadaan uang digital bitcoin. Karena keberadaan bitcoin yang ada saat ini berbeda dengan e-money yang lebih dahulu beredar, meskipun bitcoin bersifat digital/elektronik seperti $e$-money pada umumnya namun ada sesuatu yang menjadikan transaksi bitcoin berbeda dengan e-money pada umumnya. Apabila pada e-money biasanya berupa kartu atau cek sebagai representasi nilai yang dimiliki, akan tetapi pada bitcoin tidak ada wujud dari representasi nilai yang dimiliki, semua nilai nominal terdapat dalam suatu sistem computer yang berbentuk wallet (Sholihah, 2014).

Disamping memiliki kelebihan yang efisien, sangat rahasia, dan bisa digunakan dalam transaksi global, bitcoin juga memiliki kekurangan. Diantara kekurangan yang paling mendasar yaitu tidak adanya control dari lembaga yang berwenang seperti OJK ataupun Bank Indonesia. Sebuah sistem juga dituntut agar mampu menyeimbangi perkembagan zaman. Oleh karena itu perlu adanya sebuah rekontruksi teknologi juga didukung dengan undang-undang yang memayungi adanya peredaran uang digital tersebut. Bentuk kerja sama yang selaras tersebut diharapkan mampu menciptakan sebuah sistem yang lebih inklusif serta dapat mewujudkan stabilitas keuangan yang baik.

\section{Analisis Mata Uang berbasis Syariah}

Secara umum uang berfungsi sebagai alat tukar, penyimpan nilai, satuan perhitungan dan sebagai standar pembayaran utang yang tertunda (Iqbal, 2010). Sukirno (2010) menyatakan bahwa sebagai alat transaksi yang dapat diterima oleh masyarakat, uang harus memenuhi syarat 1) mudah dibawa; 2) mudah disimpan; 3) tahan lama; 4) nilainya tidak mengalami perubahan; 5) jumlah terbatas; 6) memiliki mutu yang sama. Beberapa ulama memberikan pandangan yang beragam mengenai sistem pembayaran dan ditunjukkan pada Tabel 2.

Menurut pandangan Imam Ghazali dapat diambil pengertian bahwa beredarnya uang kertas yang kita gunakan sebagai alat tukar adalah atas legalitas pemerintah. Sekiranya pemerintah mencabut keputusannya dan mengganti mata uang dengan jenis yang lain maka uang kertas tersebut tidak akan memiliki bobot sama sekali. Ibnu Kholdun memiliki pandangan bahwa ketentuan diberlakukannya mata uang selain emas adalah dengann syarat tetap menjadikan emas sebagai standar mata uang. Transaksi keuangan dengan sistem mata uang emas berarti mewakilkan uang kertas dengan emas sebesar nilai yang tertulis pada uang kertas tersebut (uang kertas substitusi). Dengan begitu pemerintah tidak akan menambah jumlah mata uang kertas 
yang beredar, karena mata uang yang beredar harus disesuaikan dengan jumlah emas yang tersimpan. Secara tidak langsung, penggunaan emas standar mata uang juga akan meminimalisir masalah krisis global ataupun inflasi.

Tabel. 2 Pandangan Ulama mengenai Sistem Pembayaran

\begin{tabular}{|l|l|}
\hline \multicolumn{1}{|c|}{ Tokoh } & \multicolumn{1}{c|}{ Pandangan Tokoh } \\
\hline $\begin{array}{l}\text { Imam } \\
\text { Ghazali }\end{array}$ & $\begin{array}{l}\text { boleh beredar alat bayar resmi selain emas dengan ketentuan } \\
\text { pemerintah yg melegalkan (Billah, 2010). }\end{array}$ \\
\hline $\begin{array}{l}\text { Ibnu } \\
\text { Khaldun }\end{array}$ & $\begin{array}{l}\text { boleh beredar alat bayar resmi selain emas dan perak dengan } \\
\text { ketentuan tetap menjadikan emas dan perak sebagai standar } \\
\text { nilai (Billah, 2010). }\end{array}$ \\
\hline $\begin{array}{l}\text { Ibnu } \\
\text { Taimiyyah }\end{array}$ & $\begin{array}{l}\text { Fulus (uang tembaga yang memiliki nilai dibawah dinar dirham) } \\
\text { dicetak secara proposional supaya tetap terjaga harga yang adil. } \\
\text { Pemerintah diharamkan mencetak fulus berlebihan yang dapat } \\
\text { merugikan masyarakat (Arini, 2015). }\end{array}$ \\
\hline
\end{tabular}

Sumber: diolah peneliti (2018)

Selanjutnya pandangan lain yang menjelaskan tentang pemanfaatan dinar dan dirham sebagai mata uang dilatarbelakangi oleh beberapa argumen, diantaranya:

a) Alat Tukar yang tepat, Uang dinar dan dirham memiliki nilai stabil di setiap negara, maka dari itu akan memberikan kemudahan untuk transaksi domestik maupun internasional. Berbeda dengan uang kertas yang membutuhkan legalitas hukum oleh pemerintah, namun dinar berlaku dengan sendirinya tanpa proses penghalalan maupun pengesahan sebagai media transaksi (Vadillo, 2002).

b) Uang yang stabil, Mata uang dinar mengandung 4,25 gram emas dengan 22 karat dan setiap negara memiliki standar yang sama. Uang dinar lebih rentan menghadapi inflasi. Tulisan Roy Jastram dari Berkeley University dalam bukunya The Goldent Constant menjelaskan bahwa nilai emas terhadap nilai komoditi untuk kurun waktu 400 tahun sampai tahun 1976 cenderung memiliki nilai yang stabil sekalipun menghadapi bencana alam, perang dan krisis ekonomi (Vadillo, 2002).

c) Meminimalisar spekulasi, praktik spekulasi dan arbitrase di pasar valuta asing akan berkurang karena mata uang yang digunakan memiliki nilai yang sama. Berbeda dengan uang kertas yang bisa dimanfaatkan oleh spekulator mencari keuntungan dari perbedaan nilai mata uang laen (Meera, 2002). 
Dalam menentukan kelayakan suatu entitas untuk dijadikan mata uang maka perlu adanya uji kelayakan dengan menilai syarat dan ciri-ciri khusus dari entitas tersebut. Dalam sejarah ekonomi modern, dipilihnya emas dan perak sebagai bahan mata uang memiiki kelebihan tersendiri dibandingkan dengan bahan-bahan yang lain. Sebab kedua bahan tersebut dinilai memenuhi syarat untuk dijadikan mata uang. Syarat-syarat tersebut adalah (Dimyati, 2008):

a) Generally acceptability (diterima secara luas)

b) Stability of value (stabilitas nilai atau harga)

c) Portability (bentuknya simple)

d) Durability (tahan lama)

e) Difficult to imitate (sukar dipalsu)

f) Divisible to small units (mudah dibagi menjadi bagian-bagian kecil)

g) Suplainya elastis

h) Continuity

i) Mudah disimpan

Terealisasinya mata uang yang adil merupakan salah satu prinsip roda penggerak ekonomi islam. Sebagaimana disebutkan oleh Imam Ghazali "sebagai hakim yang adil", beberapa ekonom islam memaknai emas dan perak sebagai penentu harga, standar nilai bagi semua jenis komoditas dan jasa, bukan sebaliknya yang nilainya ditetapkan melalui fantasi yang dibubuhkan pada uang kertas (Saidi, 2011). Sifat dinar dan dirham yang dianggap universal dan tidak mengenal negara, sehingga jika penggunaannya dapat terealisasikan, maka akan tercapai sistem keuangan yang adil bagi semua umat (Setiawan, 2010).

Dinar dan dirham layak untuk dijadikan sebagai alat transaksi karena dua koin mata uang tersebut memiliki nilai dan unsur yang stabil. Ibnu Kholdun mengungkapkan dalam Ekonomi Makro Islam, bahwa suatu negara tidak akan mungkin dapat melakukan pembangunan secara sustainable tanpa adanya keadilan dalam sistem yang dianutnya. Artinya bahwa stabilitas harga memiliki jaminan keadilan uang dalam fungsinya, sehinggga perekonomian akan relatif berada dalam kondisi stabil.

\section{Rekonstruksi Pembentukan DGC}

Digital Gold Curreny (DGC) terbentuk dari perpaduan model mata uang emas (gold currency) dengan teknologi mata uang digital (digital Currency) yang selanjutnya disesuaikan dengan Nilai-nilai syari'ah. Rekontruksi pembentukan DGC ditunjukkan pada Gambar 2.

Penggunaan emas sebagai standar mata uang dirasa lebih stabil nilainya dibanding dengan penggunaan uang kertas (Fiat Money). Dalam sejarah uang, emas 
sampai saat ini terbukti masih digunakan sebagai alat bayar dan alat simpan kekayaan. Penggunakan emas sebagai standar mata uang berarti kembali ke uang yang sebenarnya, penggunaan emas di masa lalu sudah berjalan brabad-abad tidak pernah lapuk dimakan waktu baik nilainya maupun fungsinya. Redupnya popularitas penggunaan uang emas sebagai alat bayar dikarenakan kebanyakan orang bahkan para komunitas uang emas saat ini berpandangan emas hanya dipahami sebagai alat simpan.

Digital Gold Curreny (DGC) mengkombinasikan emas sebagai standar mata uang dengan pemaksimalan perkembangan teknologi. DGC memanfatkan teknologi yang sudah tersedia sebagai mana beberapa instrumen perbankan yang sudah berkembang dengan basis teknologi seperti internet banking, mobile banking,e-banking, dll. Penulis memilih nama Digital Gold Currency (DGC) sebagai penamaan mata uang emas berbasis digital, istilah tersebut merupakan bentuk modifikasi dari beberapa istilah yang sudah ada pada inovasi mata uang modern. Penggunaan istilah Digital Gold Currency (DGC) sudah dapat mengakomodir istilah gold currency digital payment system, Istilah DGC di situ otomatis sudah mengakomodir fungsi uang itu sendiri sebagai alat pembayaran, menyimpan nilai yang dapat diakses melalui elektronik, celuller/mobile, atau komputer.

Pembentukan Digital Gold Curreny (DGC) disesuakan juga dengan nilainilai syari'ah Islam. Di dalam ekonomi Islam ada beberapa acuan terkait mata uang, diantaranya: Pertama, fungsi uang diakui hanya sebagai alat tukar (medium of exchange) dan kesatuan hitung (unit of account). Uang itu sendiri tidak memberikan kegunaan/manfaat, akan tetapi fungsi uanglah yang memberikan kegunaan. Uang menjadi berguna jika ditukar dengan benda yang nyata atau jika digunakan untuk membeli jasa.oleh karena itu uang tidak bisa menjadi komoditi/barang yang dapat diperdagangkan (Muhaimin, 2010). Kedua, Al-Quran dan As Sunnah banyak menyebutkan harta dan kekayaan dengan Istilah Emas dan Perak (dinar dan dirham). Keyakinan ini semakin mendorong penggunaan atas keduanya meski tidak ada keharusan. Ketiga, sebagai upaya dalam rangk menegakkan rukun Islam yaitu membayar zakat dan menegakkan hukum Islam yaitu hukuman bagi pencuri yang ukuran standarnya adalah dinar dan dirham. Keempat, bahwa uang emas bersifat universal, nilainya relatif stabil dan dapat diterima oleh setiap manusia sehingga dapat digunakan untuk transaksi lokal dan Internasional.

Nantinya pengguna Digital Gold Curreny (DGC) dapat menggunakan DGC untuk segala transaksi non tunai pemindahan dana secara cepat, aman, dan efisien baik untuk transaksi barang maupun transaksi jasa, pemindah bukuan atau transaksi yang bersifat sosial seperti Zakat, Infaq, Shadaqoh,Wakaf Tunai, dll. 


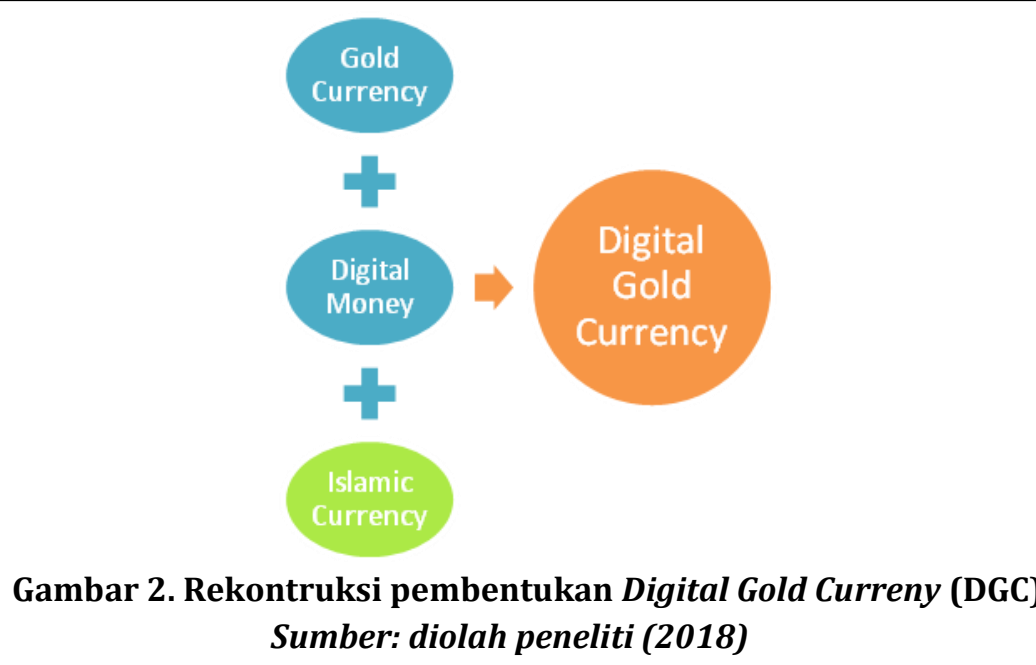

Nilai yang tercantum di DGC sesuai dengan nilai emas saat itu, sehingga pengguna dapat melakukan top up dengan uang kertas (fiat money) melalui perbankan. Nilai Digital Gold Curreny (DGC) juga akan berkurang ketika digunakan untuk bertransaksi yang krusnya disesuaikan dengan standar nilai emas saat penggunaan. Pemanfaatan DGC yang memperhatikan nilai-nilai syariat Islam juga akan memperhatikan aktivitas ekonomi yang baik (halal) dan Bermanfaat (thoyib).

\section{Mekanisme Operasional DGC}

Digital Gold Curreny (DGC) digunakan secara online, sehingga tidak melibatkan fisik emas secara langsung. Hal ini sama dengan sistem the gold exchange standard yang menggunakan satuan nilai yang disetarakan dengan emas. Perbedaanya adalah bentuk yang mewakili adalah uang digital sehingga mengurangi biaya produksi dan distribusi, sehingga nilainya akan tetap sama dengan nilai emas. Menggunakan sistem ini maka uang kertas dapat ditebus dengan emas menggunakan nilai dari jual dan beli emas.

Rekening tersebut berlaku selayaknya akun rekening pada umumnya. Nasabah dapat melakukan setor (top up) atau penarikan dalam bentuk mata uang/fiat atau emas fisik jika jumlah fiat dalam rekening telah memenuhi harga fisik emas yang beredar di pasar. Penarikan dilakukan dapat melalui DGC Bank maupun secara online dengan emas fisik di kirimkan ke nasabah yang bersangkutan, berikut ditunjjukan pada Gambar 3.

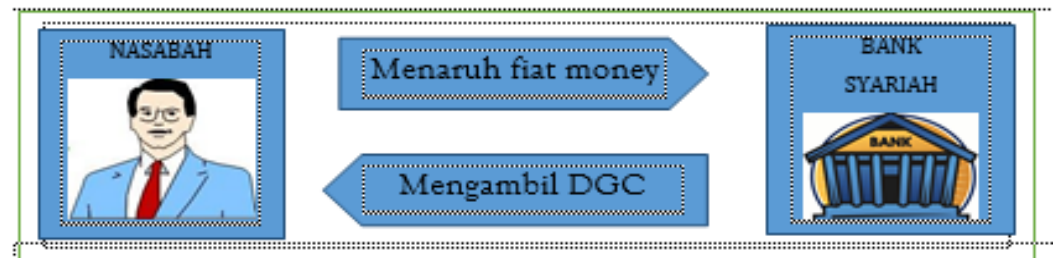

Gambar 3. Top up rekening DGC

Sumber: diolah peneliti (2018) 
Sebagai ilustrasi adalah sebagai berikut:

1. Nasabah baik individual maupun institusi

2. Tidak memasukkan biaya Administrasi

3. Harga emas digunakan current price (angka ilustrasi)

Ilustrasi:

Pada 1 Agustus 2017 harga jual emas Rp. 500.000/gram, dan harga beli emas Rp. 475.000,00. Nasabah menaruh uang Rp. 5.000.000,00 yang berarti sama saja rekening nasabah bertambah senilai 10 gram emas. Dalam rekening nasabah tertulis 10 gram emas dan kurs dalam rupiah menggunakan harga beli senilai Rp 4.750.000,00. Perhitungan 10 gram emas X Rp 475.000,00. Pada 1 Agustus 2018 harga jual emas Rp. 600.000/gram. dan harga beli emas Rp. 550.000,00. Maka rekening DGC milik nasabah tertulis 10 gram emas dan kurs menggunakan harga beli senilai Rp 5.500.000,00.

Adapun trading dalam DGC yaitu penarikan dari rekening dapat berupa emas batangan maupun fiat money menggunakan nilai jual beli emas, ilustrasinya pada Gambar 4. Asumsi :

1. Nasabah baik individual maupun institusi

2. Tidak memasukkan biaya Administrasi

3. Harga emas digunakan current price (angka ilustrasi)

Ilustrasinya adalah sebagai beriku, misalkan pada 1 Agustus 2018 harga jual emas Rp. 600.000/gram, dan harga beli emas Rp. 550.000,00. Nasabah memiliki rekening 10 gram emas dengan kurs dalam rekening senilai Rp 5.500.000,00. (Perhitungan 10 gram emas X Rp 550.000,00). Nasabah bisa mengambil dalam bentuk mata uang yang berlaku di wilayah tersebut atau emas batangan dengan menganti biaya cetak emas batangan. Misal nasabah mengambil emas fisik seberat 5 gram, berarti rekening nasabah dikurangi senilai Rp 2.750.000,00. (Perhitungan 5 gram emas X Rp 550.000,00).

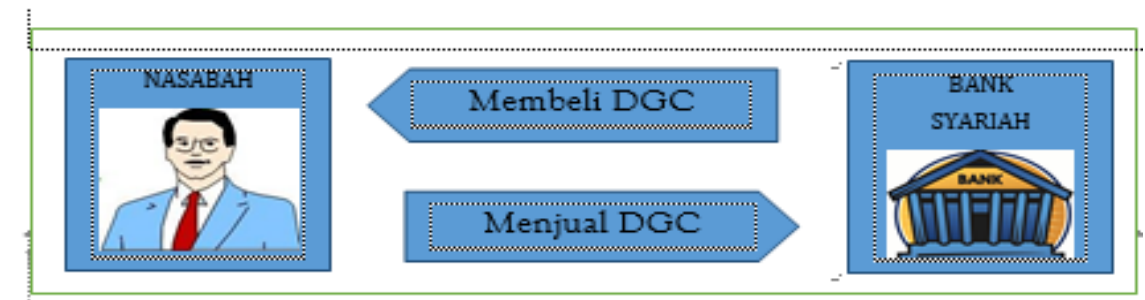

Gambar 4. Transaksi Via DGC Sumber: diolah peneliti (2018) 


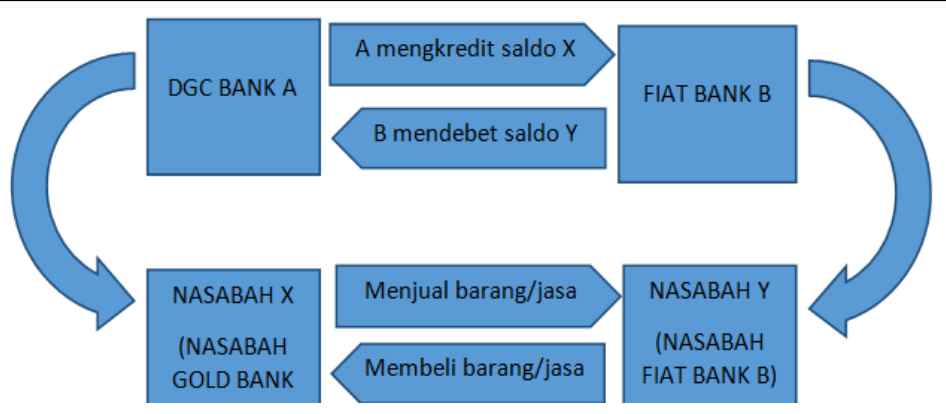

Gambar 5. Transaksi Pengguna DGC dengan Fiat Money Sumber: diolah peneliti (2018)

Ilustrasi transaksi penggunaan DGC dengan flat money ditunjukkan pada gambar 5. Misalkan, pada 1 Agustus 2018 harga jual emas Rp. 600.000/ gram, dan harga beli emas Rp. 550.000,00. X memiliki saldo di bank A sebesar 10 gram emas dengan kurs Rp 5.500.000,00 . dan Y memiliki Rp 6.000.000 di bank B. X menjual sebuah TV LED seharga Rp 2.4000.000,00 atau setara dengan 4 gram emas dan $\mathrm{Y}$ sepakat melakukan transaksi, maka bank A menkredit saldo X sebesar (4 gram x 550.000) Rp 2.200.000,00 sehingga saldo X menjadi Rp 7.700.000 dan rekening emas 14 gram sedangkan bank B mendebit saldo Y senilai harga jual emas, yaitu Rp 2.400.000,00. Sehingga saldo Y menjadi Rp 3.600.000,00.

Transaksi sesama pengguna DGC dapat terjadi lebih mudah, sebagaimana transaksi yang terjadi antar nasabah perbankan. Ilustrasinya adalah adaah pada Gambar 6. Misalkan, pada 1 Agustus 2018 harga jual emas Rp. 600.000/ gram, dan harga beli emas Rp. 550.000,00. X memiliki saldo di bank A sebesar 10 gram emas dan Y memiliki 15 gram di bank B. X menjual sebuah TV LED seharga 4 gram emas dan Y sepakat melakukan transaksi, maka bank A menkredit saldo X sebesar 4 gram sehingga saldo X menjadi 14 gram sedangkan bank B mendebit saldo Y senilai harga jual emas, yaitu 4 gram. Sehingga saldo Y menjadi 11 gram emas.

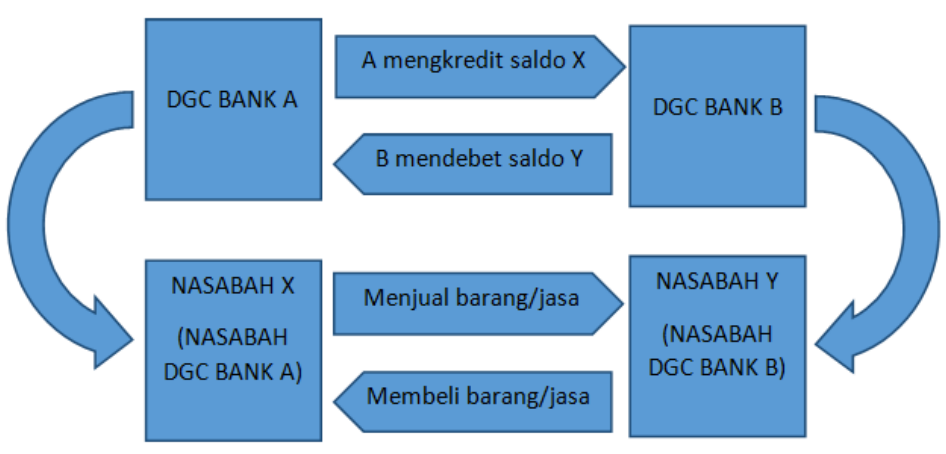

Gambar 6. Transaksi sesama pengguna DGC Sumber: diolah peneliti (2018) 


\section{Instansi-instansi pedukung DGC}

Pembentukan sistem Digital Gold Currency (DGC) membutuhkan peran dari berbagai lembaga/instansi yang saling terkait, antara lain sebagai berikut:

1. Bank Indonesia / Bank sentral

Bank Indonesia sebagai bank sentral Indonesia memiliki peran mengatur, mengawasi dan membuat regulasi moneter negara. Bank Indonesia (BI) harus mampu mengakomodir tentang Digital Gold Currency (DGC) sebagai mata uang emas digital. Secara substansi keberadaan uang emas sudah berjalan beratus-ratus tahun dan masih berlaku sampai saat ini meskipun tidak secara langsung. Uang sebagai alat simpan kekayaan masih berjalan sampai saat kini, hanya uang sebagai alat bayar perlahan sudah berkembang dengan transaksi non tunai, namun setelah ditemukan sistem informasi akuntansi antar bank, nasabah, serta pencatatan, bank Indonesia harus mampu mengakomodir terciptanya uang emas, tanpa menghapus uang kertas yang ada. Keberadaan Digital Gold Currency (DGC) memerlukan perangkat digital yang menampilkan nilai nominal uang dan emas saat itu.

2. Otoritas Jasa Keuangan (OJK),

Otoritas Jasa Keuangan (OJK) menyelenggarakan sistem pengaturan dan pengawasan yang integrasi terhadap keberlangsungan Digital Gold Currency (DGC) sebagai mata uang digital berbasis Syariah. Sehingga keseluruhan kegiatan dalam sektor keuangan terselengara secara teratur, adil, transparan dan akuntabel. Sistem keuangan negara akan mampu tumbuh berkelanjutan dan stabil. Melindungi kepentingan konsumen dan masyarakat dalam mengunakan Digital Gold Currency (DGC).

3. Majlis Ulama Indonesia (MUI)

Majlis Ulama Indonesia (MUI) melalui Dewan Syariah Nasional (DSN) memiliki peran menumbuhkembangkan penerapan nilai-nilai syariah dalam kegiatan perekonomian pada umumnya dan pada sektor keuangan pada khususnya. Di sini DSN-MUI mengeluarkan fatwa sekaligus mengawasi penerapan fatwa mengenai praktik keberlangsungan Digital Gold Currency (DGC). Supaya DGC sebagai mata uang digital tetap mengedepankan nilai-nilai Syariah. Sehingga dengan fatwa itu bisa menjadi landasan bagi ketentuan dan peraturan yang dikeluarkan oleh instansi yang berwenang dalam menjalankan Digital Gold Currency (DGC) sebagai mata uang berbasis Syariah.

4. Bank Syariah / Operator Digital Gold Currency (DGC).

Bank Syariah / Operator Digital Gold Currency (DGC) melayani sistem pembayaran secara elektronik. Nasabah dapat mendepositkan sejumlah uang yang nanti masuk ke akun rekening nasabah dengan otomatis terkonversi dalam nilai emas. Bank Syariah menerbitkan sertfikat emas 
serta menerbitkan User dan PIN. kemudian melaporkan kepada nasabah dan bank Indonesia secara current time (setiap saat) secara elektronik yang dapat diakses oleh media digital.

5. Nasabah baik perorangan maupun intitusional/lembaga.

Nasabah mula-mula mendepositkan sejumlah emas lalu emas di sirkulasikan oleh bank tersebut sesuai dengan penggunaan pembayaran yang dilakukan nasabah kepada PIN yang di miliki patner yang melakukan pembayaran yaitu baik individual maupun institusi seperti membayar telepon, listrik bensin di SPBU atau super market bahkan ke warung kopi, sembako, pasar tradisional atau bahkan ke pada pengamen, pengemis. Yang penting bagi nasabah adalah nomor PIN dan memiliki saldo emas di bank atau operator uang emas. Ada tiga pilar dimulainya penggunakan uang emas seluler kepada masyarakat secara luas. Gold money dapat dipalikasikan degan teknologi informasi yang handal yang dapat diakses secara seslluler sehingga dalam proses pembayaran disegala aspek dapat dilaksanakan. Begitu juga lembaga keuangan sebagai operator uang emas seluler dapat dipercaya dan transparan sertah canggih dalam pencatatan, transfer dan pelaporan. Begitu juga perlu riset-riset yang berhubungan dengan penggunaan uang emas seluler untuk digunakan alat bayar.

\section{KESIMPULAN}

Penelitian ini merupakan rekontruksi inovasi mata uang yang ditawarkan sebagai instrumen mata uang masa depan. Sebagai mana perkembangannya uang yang ada saat ini sudah mengalami evolusi dari model pembayaran barter (comodity vs comodity), Uang Barang (Comodity Money), Uang Logam (metalic Money), Uang Kertas dan Uang Logam (Fiat Money dan Metalic Money) kemudian berkembang menjadi uang berbasis teknologi (E-Money dan Digital Money). Rekontruksi mata uang baru ini terbentuk dari perpaduan model mata uang emas (gold currency) dengan teknologi mata uang digital (digital Currency) yang selanjutnya disesuaikan dengan Nilai-nilai syari'ah, perpaduan dari elemen tersebut yang kemudian menjadi inovasi mata uang baru denga istilah Digital Gold Curreny (DGC).

Terbentuknya Digital Gold Curreny (DGC) sebagai instrumen mata uang dengan mempertimbangkan hal-hal tertentu:

a. Pemanfaatan teknologi dalam Digital Gold Curreny (DGC) untuk memberikan kemudahan dan keamanan bertransaksi sebagai mana beberapa instrumen perbankan yang sudah berkembang dengan basis teknologi seperti internet banking, mobile banking,e-banking, dll.

b. Penggunaan emas sebagai standar mata uang dirasa lebih stabil nilainya dan berlaku secara universal. 
c. Penerapan nilai-nilai keislaman dalam pembentukan Digital Gold Curreny (DGC) dengan melihat fungsi uang dalam Islam, pengunaan dinar dan dirham di era kejayaan Islam masa lalu dan memberikan kemudahan dalam mentasyarufkan harta Zakat, Infaq, Shadaqah dan Wakaf (ZISWAF).

Penelitian ini memiliki keterbatasan dengan penggunakan metode yang baru sebatas diskriptif kuantitatif dan Rekontruksi integralistik teknologi. Diperlukan penelitian lanjut terhadap Digital Gold Curreny (DGC) mengenai respon masyarakat, peran lembaga keuangan syariah dan regulasi dari pemerintah. Harapan penelitian ini dapat menjadi masukan inovasi teknologi mata uang bagi lembaga keuangan dan pemerintah sebagai pemangku kebijakan terhadap perkembangan Fintech (Financial Tecnologi) yang pertumbuhannya semakin pesat.

\section{DAFTAR PUSTAKA}

Abbas, Anwar. (2012). Sistem Ekonomi Islam: Suatu Pendekatan Filsafat, Nilai-nilai Dasar, dan Instrumental. Jurnal Al-Iqtishad. Vol. 04, No. 01.

Abdullah bin Sulaiman al-Mani'. (1996). Buhuts fi al-Iqtishad al-Islami. alMaktab al-Islami, Makkah.

Karim, Adiwarman A. (2008). Ekonomi Makro Islam. Jakart: PT. Raja Grafindo Persada.

Bahri, Asep Saiful. (2010). Konsep Uang Elektronik dan Peluang Implementasinya pada Perbankan Syariah. Skripsi-UIN Syarif Hidayatullah. Jakarta

Billah, Ma'sum. (2010). Dinar Emas: Mata uang islam, alih bahasa oleh Yusuf Hidayat. Sweet and Maxwell Asia, Selangor.

Chapra, M. Umer. (1999). Islam dan Tantangan Ekonomi, Islamisasi Ekonomi Kontemporer, diterjemahkan Nur Hadi Ihsan dan Rifki Amar. Risalah Gusti, Surabaya.

Christopher, Lass dan Bryan L. Davies. (1994). Kamus lengkap Ekonomi. Edisi Kedua. Jakarta.

Claudia I, Carrillo F. Rosa, Josep Lluis De La. dkk. (2007). Toward a Knowledge Economy. International Journal of Community Currency Research. Vol. 11.

Deny Setiawan, dkk. (2010). Kekuatan Emas dan Perak Sebagai Mata uang Dunia Suatu Studi Pendahuluan. Jurnal Ekonomi. Volume 18, No. 1.

Didin, Elok Parastiti. (2015). Analisis Penggunaan Uang Elektronik Pada Mahasiswa Fakultas Ekonomi Universitas Negeri Malang dalam jurnal JESP-Vol. 7, No 1.

Dimyati, Ahmad. (2008). Teori Keuangan Islam: Rekonstruksi Metodologis terhadap Teori Keuangan al-Ghazali. UII Press, Yogyakarta.

Ferry, Mulyanto, (2015). Pemanfaatan cryptocurrency sebagai penerapan mata uang rupiah ke dalam bentuk digital menggunakan teknologi bitcoin. Indonesian Journal on Networking and Security. Volume 4. No 4. 
Hardiwinoto. (2008). Cellular Gold Money For Currency dalam Sistem Keuangan Masa Kini. Jurnal UNIMUS Value Added. Vol. 04. No. 02.

http://www.bi.go.id/id/statistik/sistem-pembayaran/uangelektronik/contents/transaksi.aspx. Diakses pada tanggal 25 September 2017. Pukul 11.25 WIB

Huda, Nurul. (2009). Ekonomi Makro Islam. Kencana, Jakarta.

Iqbal, Muhaimin. (2007). Depok: Spiritual Learning Center Mengembalikan Kemakmuran Islam dengan Dinar dan Dirham

Meera, AKM (2002). Dinar Islam. Publikasi Pelanduk, Kuala Lumpur, Malaysia.

Nabila, Diah Arini. (2015).Dinar Dirham Vs Fiat Money: Kajian teoritis penggunaan dinar dan dirham dalam perdagangan antar negara Islam. Jurnal Syariah 3.

Nur Lailatus Sholihah. (2014). Tinjauan fiqih muamalah terhadap uang digital bitcoin dengan studi pada DSN-MUI dan perusahaan Artabit.

Nurul, Huda. (2009). Ekonomi Makro Islam. Kencana, Jakarta.

Rachbini, D.J. (2002). Ekonomi Politik \& Demokrasi Ekonomi (Political Economics and Economic Democracy). Jakarta: PT Grasindo.

Robert C. Bogdan \& S.K. Biklen. (1982). Qualitative Researc for Education: An Introduction to Theory and Methods. Allyn and Bacon Inc, Boston.

Sadono, Sukirno. (2010). Makro Ekonomi Teori Pengantar. Rajawali pers, Jakarta.

Saidi, Zaim. (2007). Ilusi demokrasi: Kritik dan Otokritik Islam Menyongsong Kembalinya tata Kehidupan Islam Menurut Amal Madinah. Cetakan 1. Republika. Jakarta

Saidi, Zaim. (2011). Euforia Emas: Mengupas Kekeliruan dan cara yang Benar Pengembangan Dinar, Dirham, dan Fulus Agar Sesuai Al-Quran dan Sunnah. Cetakan 1. Pustaka Adina. Yogyakarta.

Setiawan, Deny dkk. (2010). Kekuatan Emas Sebagai Mata Uang Dunia Suatu Studi Pendahuluan. Jurnal Ekonomi. Vol. 18, No. 1.

Tazkiyaturrohmah, Rifqy. (2016). Transaksi Uanf Elektronik Di Tinjau Dari Hukum Syariah. Tesis Hukum Bisnis Syariah. Pasca Sarjana UIN Sunan Kalijaga.

Untoro, R. Wahyu Yuanita. (2014).Kajian penggunaan Instrumen Sistem pembayaran sebagai leading indicator stabilitas system keuangan.WP/5/ Desember.

Vadillo, U. (2002). The Return of Islamic Gold Dinar. Cape Town: Madinah Press

Yaacob, Salmy Edawati. (2012). Study of Implementasi Gold Dinar as Currency. World Applied Sciences Journal. Vol. 20 (7). 